\title{
How Technology in Care at Home Affects Patient Self-Care and Self-Management: A Scoping Review
}

\author{
José M. Peeters $^{1, *}$, Therese A. Wiegers ${ }^{1}$ and Roland D. Friele ${ }^{1,2}$
}

1 NIVEL, Netherlands Institute for Health Services Research, Otterstraat 118-124, Utrecht 3513 CR, The Netherlands; E-Mails: t.wiegers@nivel.nl (T.A.W.); r.friele@nivel.nl (R.D.F.)

2 Faculty of Social and Behavioural Sciences, Tilburg University, Warandelaan 2, Tilburg 5037 AB, The Netherlands

* Author to whom correspondence should be addressed; E-Mail: j.peeters@nivel.nl; Tel.: +31-30-272-9628; Fax: +31-30-272-9729.

Received: 9 September 2013; in revised form: 17 October 2013 / Accepted: 17 October 2013 / Published: 29 October 2013

\begin{abstract}
The use of technology in care at home has potential benefits such as improved quality of care. This includes greater focus on the patients' role in managing their health and increased patient involvement in the care process. The objective of this scoping review is to analyse the existing evidence for effects of technology in home-based care on patients' self-care and self-management. Using suitable search terms we searched the databases of Pubmed, Embase, Cochrane Library, Cinahl, Picarta and NIVEL dating from 2002 to 2012. Thirty-three studies (six review studies and twenty-seven individual studies) were selected. Effects were extracted from each study and were classified. In almost all the studies, the concepts self-care and self-management are not clearly defined or operationalized. Therefore, based on a meta-analysis, we made a new classification of outcome measures, with hierarchical levels: (1) competence (2) illness-management (3) independence (social participation, autonomy). In general, patient outcomes appear to be positive or promising, but most studies were pilot studies. We did not find strong evidence that technology in care at home has (a positive) effect on patient self-care and self-management according to the above classification. Future research is needed to clarify how technology can be used to maximize its benefits.
\end{abstract}

Keywords: self-care; self-management; technology; care at home; scoping review 


\section{Introduction}

\section{What is already Known about the Topic?}

- The use of technology in the care at home has potential benefits, such as improved patient outcomes, increased quality of care and increased patient involvement in the care process.

- Implementation of technology in the care at home is not always successful and it takes a long time before innovation of promising technology is implemented on a wide scale.

\section{What Does This Paper Add?}

- In our review, we found 33 studies (six review studies and twenty seven individual studies) that reported effects of technology in the care at home on patient self-care and self-management.

- In almost all of the 33 included studies the authors did not use a clear definition or operationalization of self-care and self-management.

- Most of the included studies show effects of technology on the level of increased patient competence: patients using technology have a better understanding of their disease and more knowledge of the disease.

- We did not find strong convincing evidence that technology in the care at home has (a positive) effect on patient self-care and self-management.

- These findings can help to guide future research and clinical practice that support selfmanagement efforts.

Substantial increases in the numbers of chronically ill patients, in the face of an expected reduction of staffing in health care and significant financial problems, mean that a fundamental change is required in the process of care [1]. Faced with rising demand for health care on the one hand and health system capacity constraints on the other hand, governments and care organizations are increasingly turning to new technology to help support and enhance existing services [2].

The main (expected) benefits of technology in care at home are reduced costs from less hospital utilization as well as improved health outcomes among patients with chronic illnesses, most often heart failure, diabetes or other chronic diseases [3]. Technology is being considered by homecare organizations with a view to managing costs and enabling independence for patients wishing to stay at home [4]. These potential benefits are recognised in health policy [2]. The use of technology to provide health services for independently living individuals with chronic diseases and for frail elderly is one of the most promising developments in health care nowadays.

The development and use of technology in care at home is important in the context of the growing emphasis on self-care and self-management in health care. Technology can be used as a tool to monitor symptoms of disease and therefore affords patients the opportunity to manage chronic illness. The need to manage chronic conditions and to actively engage in a lifestyle that fosters health is increasingly recognized as the responsibility of the patient. Optimal self-management entails the ability to monitor one's illness and to develop and use cognitive, behavioural, and emotional strategies to maintain a satisfactory quality of life [5]. Current evidence also indicates that patients who engage in 
self-management behaviours improve their health outcomes [6]. Self-management is especially important for those with a chronic disease, because management of the illness is a lifetime task and self-management can enable patients to make their own decisions. For these patients it is also important to learn how to cope with the disease and manage it in their daily life, in their social contacts and in their job. Technology in care at home can be used by patients, for example to monitor their symptoms, and may contribute to patients' independence, enabling them to stay at home for as long as possible.

The use of technology in care at home is a relatively new research field and the body of evidence regarding its effects is sparse [3]. There is a large gap between the postulated and empirically demonstrated benefits of technology [7]. Moreover, little is known about the effects of promising technology in terms of patient outcomes such as self-care and self-management of an illness. The aim of this review is to analyse the existing evidence for the effects of technology in home-based care on self-care and self-management.

\section{Technology in Care at Home}

Technology in care at home is a broad term and there are many different types of technology. We give some examples. Home telemonitoring is defined as an automated process for the transmission of data about a patient's health status from the patient's home to the respective health care setting $[1,8]$. Its aim is to provide information to the health professionals without their having to visit the patient.

Home telecare is focused on providing support from a distance to patients in their own home. Home telemedicine is defined as the direct provision of clinical care, including diagnosing, treating or consultation, via telecommunication. This may include the sharing of scans and visual images [1]. The primary function of home telemedicine is to provide specialist consultation to distant communities, rather than offer a tool for self-management of chronic disease. Assistive technology applications are very diverse, and can range from specific alarm and monitoring devices to ambient living technology. These can be used in several ways, for example to increase the comfort and independence of (chronically) ill patients [9]. For this paper, all these described domains of technology in care at home are included.

\subsection{Conceptualization of Self-Care and Self-Management}

A number of authors have put forward definitions of self-care and self-management. Lorig and Holman [10] defined self-management as a dynamic, interactive and daily process, aimed at helping patients maintain a wellness perspective by engaging in a set of tasks: medical management (maintaining, changing, and creating new meaningful behaviours or life roles) and emotional management (dealing with the emotional consequences of having a chronic condition). Self-care is defined as a two-phase process of (1) maintaining health through positive health practice and (2) managing a chronic disease through a process of recognizing, evaluating, and treating symptoms, and evaluating the efficacy of the treatments chosen [11]. 
Well-known conceptual frameworks have enhanced the understanding of self-care [12] and the understanding of self-management of chronic illness [10]. Riegel and Dickson [12] describe self-care as a naturalistic decision-making process involving the choice of behaviours to maintain physiological stability (maintenance) and the response to symptoms when they occur (management). The self-care process according to Riegel and Dickson [12] has five successive, hierarchical stages: (1) symptom monitoring; (2) symptom recognition; (3) symptom evaluation; (4) treatment implementation; (5) treatment evaluation. Lorig and Holman [10] attempt to give meaning and substance to the term self-management and present six core self-management skills: (1) problem solving; (2) decision making; (3) resource utilization; (4) forming of a patient/health care provider partnership; (5) taking action; (6) self-tailoring.

\subsection{Research Focus}

Although expectations about the impact of health technology on patient self-care and self-management are high, until now the evidence is not clear. This study expands on the growing body of literature on this subject and focuses on the effects of technology in care at home on patient self-care and self-management, irrespective of the specific type of technology. We have not made selections or applied any quality constraints in relation to the technology.

The research question we aim to answer is: "What are the effects of the use of technology in care at home on patient self-care and self-management?"

The goals of our review are: (1) to analyse the evidence for the effects of technology in the care at home on patient self-care and self-management, without limiting the type of technology used or the target group it is intended for; (2) to identify knowledge gaps in the existing literature.

\section{Methods}

\subsection{Scoping Review}

We conducted a scoping review on the impact of technology in care at home. Scoping reviews represent an increasingly popular approach to reviewing health research evidence [13]. Definitions commonly refer to "mapping" a range of evidence in order to convey the breadth and depth of a field [14]. In this study, we used a scoping review because a narrow research question could not be defined [15]. Scoping studies differ from systematic reviews because authors typically do not assess the methodological quality of the included studies [15,16]. Scoping studies also differ from narrative or literature reviews in that the scoping process requires analytical reinterpretation of the literature [13].

\subsection{Literature Search}

A comprehensive literature search was conducted in July 2012. The keywords (i.e., technology, home telecare, telemonitoring, telemedicine, telecommunication, community dwelling, independent living, self-care, self-management, disease-management) were determined after an initial broad search of the literature and consultations by two of the authors (JP, TW) with a librarian. We decided to use a broad search string to make sure we would identify as many relevant studies as possible. The following main databases for the subject of our study were searched: 
(1). PUBMED (United States National Library of Medicine)

(2). EMBASE (Excerpta Medica Database)

(3). COCHRANE LIBRARY (Cochrane Database of Systematic Reviews, Cochrane Central Register of Controlled Trials, Cochrane Methodology Register, Database of Abstracts of Reviews of Effects, Health Technology Assessment Database, NHS Economic Evaluation Database)

(4). CINAHL (Cumulative Index to Nursing and Allied Health Literature)

(5). PICARTA (Dutch Central Catalogue NCC and the Online Contents)

(6). NIVEL (Netherlands Institute for Health Services Research)

Table 1 shows which search terms were used for these databases.

Table 1. Search terms.

\begin{tabular}{l} 
"Technology" search terms: \\
Technology, homecare, hometelecare, telecommunications, telemonitoring, telemedicine, \\
teleconsultation, e-health, telehealth, telenursing, smart phone, mobile device, apps, ipad, social \\
media, sms, robotics, remote care, remote sensing, video-communication, e-coaching, mobile \\
health, m-health, gaming, health 2.0, wireless communication, data storage device, computer \\
storage device, mobile device, electronic care, gerotechnology, sensor, camera, webcam, domotica \\
\hline "Self-(disease)management/self-care" terms: \\
Self-care, self-management, disease management, independence \\
"Care at home" terms: \\
Care at home, home care, assisted living, assisted living facilities, independent living, home bound \\
patients, home bound persons, community dwelling, ambient assisted living, home environment, \\
patients home
\end{tabular}

\subsection{Search Terms and Strategy}

A combination of free-text and thesaurus terms were used. "Technology" search terms were combined with "self-care/independence" or "self-(disease) management" search terms and with "care at home" search strings (see Table 1 for details). In addition to the searches in the literature databases, reference lists of included systematic literature studies (e.g., [1,17]) were screened. All references tracked down were entered in Reference Manager, where double entries were removed. We also removed publications without abstract and publications that did not provide research results, such as opinion letters, book chapters, commentaries, models or proposals for research.

\subsection{Inclusion and Exclusion Criteria}

We applied limitations for:

(1) year of publication: only from 2002 to 2012;

(2) language: published in the English language;

(3) type of publication: appearing in peer-reviewed journals;

(4) country: only Western, Anglo-Saxon or Asian countries. 


\subsection{Inclusion Criteria}

The following inclusion criteria were used:

- The study is aimed at technology for patients living at home (sheltered housing, e.g., for persons with disabilities, was also included).

- The publication documents outcome effects of technology, i.e., patients self-management, disease management, self-care or independence.

No criteria for patient groups or research designs were applied. Publications about the same study were considered as one study, for analytical purposes.

\subsection{Exclusion Criteria}

The following exclusion criteria were used:

- Studies that focussed exclusively on the technology itself, or on technology that is used only by care providers.

- Studies in which technology features, but is not the focus of the study, for example studies about technology-dependent children.

The references found were assessed in two steps, to ascertain whether they were eligible for inclusion. The first step involved the title and the abstract; the second step concerned the full text. The assessment was based on content-analysis and performed by two reviewers (JP, TW), independently of each other. Disagreements between the reviewers on whether to include or exclude a publication were discussed until consensus was reached.

\subsection{Data Extraction and Synthesis}

A spread sheet was created to chart the information that contributed to answering the research question. Subsequently, the following data from the included studies were extracted: year of publication, country where the research was conducted, number of patients involved in the study, patient category (e.g., chronic disease), technology used and observed effects. The data extraction was conducted by one reviewer (TW). The information extracted for the purpose of answering the research questions was checked by a second reviewer (JP). The results were evaluated in a narrative format to provide a detailed summary and comparison of the technology used in care at home, across the reported outcome measures of our review.

\subsection{Search Results}

The initial search actions resulted in 5,117 hits in total. After removing duplicate articles and articles without an abstract, 3,380 references remained. The inclusion flow is depicted in Figure 1.

After selecting references by title and abstract, there were 159 left to be judged for inclusion based on their full text. Most of these studies were excluded, based on the inclusion and exclusion criteria (see above). In this phase, 30 studies remained. Screening of the references contained in the review studies yielded another 64 possibly relevant references that were not already included in our database. Ultimately, 33 studies (6 review studies and 27 individual studies) were selected for inclusion for data 
extraction and analysis and provided the main empirical evidence base in relation to assessing the effects of technology on patient self-care and self-management in care at home.

Figure 1. Flow chart of study inclusions.
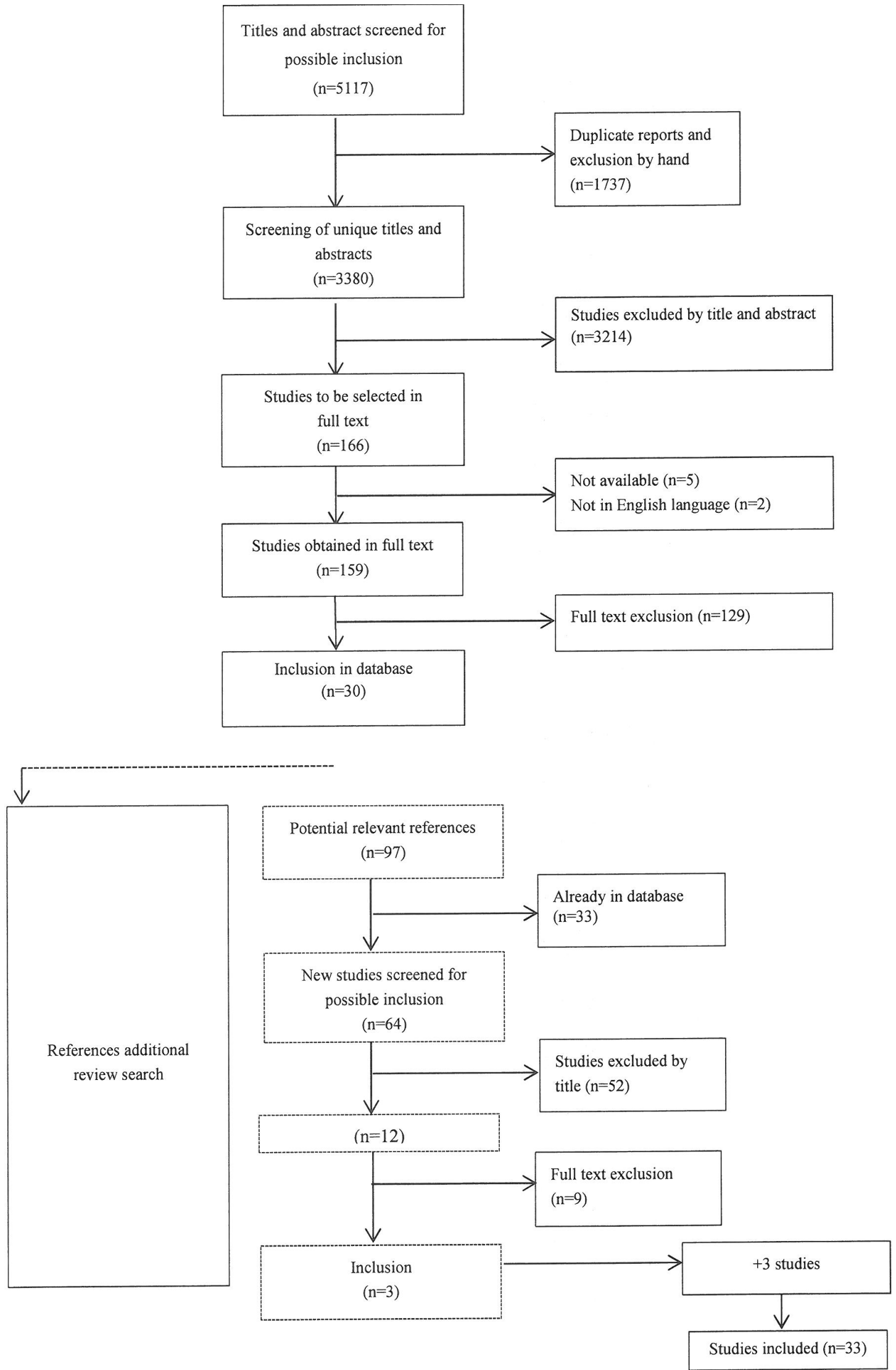
Table 2. Study characteristics and results.

\begin{tabular}{|c|c|c|c|c|c|}
\hline $\begin{array}{c}\text { Author and year of } \\
\text { publication }\end{array}$ & Country & Type of patients & Type of study & Sample & Type of technology \\
\hline \multicolumn{6}{|c|}{ Reviews } \\
\hline Paré et al., 2007 [1] & Canada & chronic diseases & systematic review & $\begin{array}{l}65 \text { studies, number of } \\
\text { patients not mentioned }\end{array}$ & $\begin{array}{l}\text { telemonitoring: the use of audio, video and } \\
\text { other telecommunication technologies to } \\
\text { monitor patient status at a distance }\end{array}$ \\
\hline $\begin{array}{l}\text { Bowles \& Baugh, } \\
2007[2]\end{array}$ & USA & $\begin{array}{l}\text { adult patients with } \\
\text { chronic illness }\end{array}$ & summary of publications & $\begin{array}{l}19 \text { studies } \\
\text { (28 papers) }\end{array}$ & $\begin{array}{l}\text { telehomecare: telehealth technology with } \\
\text { peripheral medical devices }\end{array}$ \\
\hline $\begin{array}{c}\text { Stumbo et al., } 2009 \\
{[17]}\end{array}$ & USA & $\begin{array}{l}\text { individuals with } \\
\text { disabilities }\end{array}$ & $\begin{array}{l}\text { literature and } \\
\text { research synthesis }\end{array}$ & $\begin{array}{l}71 \text { studies, number of } \\
\text { patients not mentioned }\end{array}$ & assistive technology \\
\hline $\begin{array}{c}\text { Gately et al., } 2008 \\
{[18]}\end{array}$ & UK & $\begin{array}{c}\text { patients with } \\
\text { long-term conditions }\end{array}$ & $\begin{array}{c}\text { synthesis of } \\
\text { qualitative studies }\end{array}$ & $\begin{array}{l}12 \text { studies, } \\
253 \text { patients }\end{array}$ & health technologies at home \\
\hline $\begin{array}{c}\text { Jaana \& Paré } 2007 \\
{[19]}\end{array}$ & Canada & diabetes & literature review & $\begin{array}{l}17 \text { studies, } \\
1,535 \text { patients }\end{array}$ & $\begin{array}{l}\text { telemonitoring: transmission and remote } \\
\text { interpretation of patients' data }\end{array}$ \\
\hline $\begin{array}{c}\text { Jaana et al., } 2007 \\
{[20]}\end{array}$ & Canada & hypertension & literature review & $\begin{array}{c}14 \text { studies, } \\
1,119 \text { patients }\end{array}$ & $\begin{array}{l}\text { telemonitoring: automated timely } \\
\text { transmission of data, without involvement of } \\
\text { health professionals }\end{array}$ \\
\hline \multicolumn{6}{|c|}{ Individual studies } \\
\hline $\begin{array}{c}\text { Gomez et al., } 2002 \\
{[21]}\end{array}$ & Spain & diabetes & $\begin{array}{l}\text { collecting data } \\
\text { via patient unit }\end{array}$ & 10 patients & $\begin{array}{l}\text { telemedicine system: blood glucose readings } \\
\text { downloaded in patient unit }\end{array}$ \\
\hline $\begin{array}{c}\text { Bujnowska-Fedak } \\
\text { et al., } 2011 \text { [22] }\end{array}$ & Poland & diabetes & $\begin{array}{l}\text { monitoring at home, } \\
\text { patient questionnaires }\end{array}$ & $\begin{array}{c}100 \text { patients } \\
\text { (50 intervention group, } \\
50 \text { control group) }\end{array}$ & telehome diabetes monitoring and treatment \\
\hline
\end{tabular}


Table 2. Cont

\begin{tabular}{|c|c|c|c|c|c|}
\hline $\begin{array}{c}\text { Author and year } \\
\text { of publication }\end{array}$ & Country & Type of patients & Type of study & Sample & Type of technology \\
\hline $\begin{array}{c}\text { Bowles \& Dansky, } \\
2002 \text { [23] }\end{array}$ & USA & diabetes & $\begin{array}{l}\text { patient questionnaires and } \\
\text { care providers scores }\end{array}$ & $\begin{array}{c}174 \text { patients } \\
\text { (84 intervention group, } \\
90 \text { control group) } \\
\end{array}$ & telehomecare: video visits \\
\hline $\begin{array}{c}\text { Frühauf et al., } 2012 \\
{[24]}\end{array}$ & Australia & psoriasis patients & $\begin{array}{l}\text { patient and provider } \\
\text { questionnaires }\end{array}$ & 10 patients & $\begin{array}{l}\text { teledermatology: mobile phone with built-in } \\
\text { camera for wireless transmission }\end{array}$ \\
\hline $\begin{array}{c}\text { Finkelstein et al., } \\
2008[25]\end{array}$ & USA & multiple sclerosis & patient questionnaires & 12 patients & home automated telemedicine \\
\hline $\begin{array}{c}\text { Pecina et al., } 2011 \\
{[26]}\end{array}$ & USA & $\begin{array}{l}\text { complex medical } \\
\text { illnesses }\end{array}$ & $\begin{array}{l}\text { qualitative telephone } \\
\text { survey }\end{array}$ & 20 patients & $\begin{array}{l}\text { telemonitoring: remote monitoring of health } \\
\text { parameters, videoconferencing }\end{array}$ \\
\hline Marziali, 2009 [27] & Canada & chronic disease & patient interviews & 18 patients & $\begin{array}{c}\text { protected website with links to e-mail- } \\
\text { addresses, discussion forum, } \\
\text { videoconferencing }\end{array}$ \\
\hline $\begin{array}{c}\text { Kuo et al., } 2012 \\
{[28]}\end{array}$ & Taiwan & stroke patients & in-home monitoring & 84 patients & $\begin{array}{l}\text { telehealthcare: } 24-\mathrm{h} \text { tracing and monitoring } \\
\text { system of health status and care use }\end{array}$ \\
\hline $\begin{array}{l}\text { LaFramboise et al., } \\
2009 \text { [29] }\end{array}$ & USA & heart failure & $\begin{array}{c}\text { patient focus groups and } \\
\text { interviews }\end{array}$ & 13 patients & $\begin{array}{l}\text { Health Buddy: device attached to a telephone } \\
\text { line, asking } 7 \text { questions daily, followed by } \\
\text { educational "pearl". }\end{array}$ \\
\hline $\begin{array}{c}\text { Dansky et al., } 2008 \\
{[30]}\end{array}$ & USA & heart failure & $\begin{array}{l}\text { patient telephone } \\
\text { interview, Self-Care of } \\
\text { Heart Failure Index }\end{array}$ & 284 patients & videobased, interactive telehealth system \\
\hline $\begin{array}{c}\text { Bowles et al., } 2010 \\
{[11]}\end{array}$ & USA & heart failure & patient interviews & 188 patients & $\begin{array}{l}\text { telehomecare equipment including } \\
\text { videophone and wireless devices }\end{array}$ \\
\hline $\begin{array}{c}\text { Finkelstein \& } \\
\text { Wood, 2011 [31] }\end{array}$ & USA & heart failure & $\begin{array}{c}\text { patient self-test, survey } \\
\text { and interview } \\
\end{array}$ & 10 patients & home automated telemedicine \\
\hline
\end{tabular}


Table 2. Cont.

\begin{tabular}{|c|c|c|c|c|c|}
\hline $\begin{array}{c}\text { Author and year of } \\
\text { publication }\end{array}$ & Country & Type of patients & Type of study & Sample & Type of technology \\
\hline $\begin{array}{c}\text { Papasifakis \& } \\
\text { Vanderveen, } 2009 \\
{[32]}\end{array}$ & USA & heart failure & patient surveys & 85 patients & self-monitoring through the use of telehealth \\
\hline $\begin{array}{l}\text { Guendelman et al., } \\
\quad 2002[33]\end{array}$ & USA & $\begin{array}{c}\text { children with } \\
\text { paediatric asthma }\end{array}$ & Health buddy, diary & $\begin{array}{l}134 \text { patients } \\
\text { (66 intervention group, } \\
68 \text { control group) }\end{array}$ & Health buddy \\
\hline $\begin{array}{c}\text { Brennan et al., } 2010 \\
\text { [34] }\end{array}$ & USA & $\begin{array}{l}\text { patients with chronic } \\
\text { cardiac disease }\end{array}$ & patient questionnaires & $\begin{array}{c}282 \text { patients } \\
\text { (146 intervention group, } \\
136 \text { control group) } \\
\end{array}$ & technology-enhanced practice \\
\hline $\begin{array}{l}\text { Vontetsianos et al., } \\
2005[35]\end{array}$ & Greece & COPD patients & $\begin{array}{l}\text { monitoring at home, } \\
\text { patient questionnaires }\end{array}$ & 18 patients & $\begin{array}{l}\text { telehealth services: transmission of health } \\
\text { data, videoconference }\end{array}$ \\
\hline $\begin{array}{c}\text { Sicotte et al., } 2011 \\
{[36]}\end{array}$ & Canada & COPD patients & $\begin{array}{c}\text { patient and care providers } \\
\text { questionnaires }\end{array}$ & $\begin{array}{l}46 \text { patients (23 intervention } \\
\text { group, } 23 \text { control group) }\end{array}$ & $\begin{array}{l}\text { telemonitoring: web phone with touch-screen } \\
\text { monitor, to enter and send data, receive } \\
\text { feedback on predetermined parameters and } \\
\text { send warnings to nursing staff }\end{array}$ \\
\hline $\begin{array}{c}\text { Wilson et al., } 2009 \\
\text { [37] }\end{array}$ & USA & $\begin{array}{c}\text { people aging } \\
\text { with disability }\end{array}$ & $\begin{array}{l}\text { home interviews and } \\
\text { telephone contacts }\end{array}$ & $\begin{array}{l}91 \text { patients ( } 47 \text { intervention } \\
\text { group, } 44 \text { control group) }\end{array}$ & $\begin{array}{l}\text { assistive technology, home modifications, } \\
\text { adjusted task performance }\end{array}$ \\
\hline $\begin{array}{l}\text { Shea \& Chamoff, } \\
2012[38]\end{array}$ & USA & $\begin{array}{l}\text { patients with } \\
\text { chronic conditions }\end{array}$ & $\begin{array}{c}\text { secondary analysis of } \\
\text { patient and care provider } \\
\text { survey data }\end{array}$ & 43 patients & $\begin{array}{l}\text { telemonitoring: data collection, knowledge } \\
\text { transfer and (asynchronous) communication }\end{array}$ \\
\hline $\begin{array}{c}\text { Cardozo \& Steinberg, } \\
2010[39]\end{array}$ & USA & $\begin{array}{c}\text { patients with chronic } \\
\text { conditions following } \\
\text { discharge }\end{array}$ & $\begin{array}{l}\text { monitoring at home, } \\
\text { patient questionnaires }\end{array}$ & 851 patients & $\begin{array}{l}\text { case-managed telemedicine: remote } \\
\text { monitoring of health status, electronic patient } \\
\text { record and Health Buddy }\end{array}$ \\
\hline $\begin{array}{c}\text { Hoenig et al., } 2003 \\
{[40]}\end{array}$ & USA & disabled elderly & patient survey, interviews & 2,368 patients & technological assistance \\
\hline
\end{tabular}


Table 2. Cont.

\begin{tabular}{|c|c|c|c|c|c|}
\hline $\begin{array}{c}\text { Author and year } \\
\text { of publication }\end{array}$ & Country & Type of patients & Type of study & Sample & Type of technology \\
\hline $\begin{array}{l}\text { Chumbler et al., } \\
2004 \text { [41] }\end{array}$ & USA & frail elderly men & $\begin{array}{l}\text { monitoring at home, } \\
\text { patient questionnaires }\end{array}$ & $\begin{array}{c}226 \text { patients } \\
\text { (111 intervention group, } \\
115 \text { control group) } \\
\end{array}$ & $\begin{array}{c}\text { distance monitoring technology: Health } \\
\text { Buddy, two-way audio-video with or without } \\
\text { biometric monitoring }\end{array}$ \\
\hline $\begin{array}{l}\text { Hui et al., } 2006 \\
{[42]}\end{array}$ & China & $\begin{array}{c}\text { older women with } \\
\text { urinary incontinence }\end{array}$ & $\begin{array}{l}\text { questionnaires and } \\
\text { focus group }\end{array}$ & $\begin{array}{l}58 \text { patients ( } 27 \text { intervention } \\
\text { group, } 31 \text { control group) }\end{array}$ & telemedicine: videoconferencing \\
\hline $\begin{array}{l}\text { Bewernitz et al., } \\
2009 \text { [43] }\end{array}$ & USA & dementia & $\begin{array}{l}\text { observing } \\
\text { three self-care tasks }\end{array}$ & 11 patients & $\begin{array}{l}\text { intercom, remote camera, pre-recorded voice, } \\
\text { synthesized voice, visual prompts }\end{array}$ \\
\hline $\begin{array}{c}\text { Evans et al., } 2011 \\
{[44]}\end{array}$ & UK & dementia & $\begin{array}{l}\text { patient questionnaires, } \\
\text { semi-structured interviews }\end{array}$ & 1 patient & $\begin{array}{c}\text { enabling smart technology: sensors and verbal } \\
\text { messages }\end{array}$ \\
\hline $\begin{array}{l}\text { Mihailidis et al., } \\
2008 \text { [45] }\end{array}$ & Canada & dementia & score sheet, video & 6 patients & $\begin{array}{l}\text { COACH system: tracking and } \\
\text { prompting system }\end{array}$ \\
\hline $\begin{array}{l}\text { Maguire et al., } \\
2005[46]\end{array}$ & UK & $\begin{array}{l}\text { cancer patients } \\
\text { receiving } \\
\text { chemotherapy }\end{array}$ & $\begin{array}{l}\text { grading system, patient } \\
\text { questionnaires and } \\
\text { interviews }\end{array}$ & $\begin{array}{l}10 \text { patients ( } 4 \text { intervention } \\
\text { group, } 6 \text { control group) }\end{array}$ & handheld computer to monitor symptoms \\
\hline
\end{tabular}




\subsection{Study Characteristics}

Table 2 shows, for each study, the authors(s) and year of publication, the country where the research was conducted, the patient category (e.g., patients with chronic diseases such as diabetes or heart failure), type of study (literature review or individual study), the number of patients involved (in the case of randomized controlled trials: number of patients in the intervention group and control group) and a brief description of the type of technology concerned.

Most studies eighteen of the 33 were conducted in the USA; six in Canada; one in Australia; and three in the United Kingdom (UK). The other studies were conducted in Asian (Taiwan, China) or European countries (Greece, Poland, Spain). The oldest publications date from 2002 [21,23,33] and the most recent from 2012, the year in which the literature search was conducted [24,28,38]. Six studies can be characterised as a (systematic) literature review or synthesis of qualitative studies, and the number of studies covered in these reviews ranged from 12 to 65 . The other 27 studies were individual in nature and the size of the research samples in these individual studies ranged from 1 to 2,368 patients (an average of 190 patients). Nine studies can be characterized as a randomized controlled trial (RCT) with one or more follow ups (see Table 2 for more details).

Patient characteristics differed considerably from one study to another: sometimes the intervention group was a select group, such as patients with diabetes, hypertension, heart failure, lung disease or dementia. Other studies were about chronic patients in general, people with disabilities, or frail or disabled elderly. Due to the broad search criteria, the types of technology used are also very different between the studies: telemonitoring, telehomecare, telemedicine, teledermatology, videoconferencing or assistive technology. Studies varied in duration from eight weeks to two years. Clearly, there is a wide range in terms of patient populations, type of technology and type of intervention.

\section{Results and Discussion}

\subsection{Effects of Technology on Self-Care and Self-Management}

Generally, the reported effects of technology use in care at home on self-care and self-management are positive or promising for the near future. This can be concluded both from the review studies and the individual studies. For example, a review of research evidence for the effects of telehomecare on patients with chronic diseases shows that technology appears to have positive effects on chronic illness outcomes, such as self-management, rehospitalizations and length of hospital stay [3]. In a systematic review of observed effects, close management of diabetic patients through telemonitoring showed a significant reduction in complications, good receptiveness by patients and improved patient empowerment and education [19]. A review of hypertension home telemonitoring presents preliminary evidence of the benefits of telemonitoring as a successful self-management approach [20]. Another systematic review of home telemonitoring of chronic diseases found it to be a promising selfmanagement approach that produces accurate and reliable data, empowers patients, influences their attitudes and behaviours, and potentially improves their medical conditions [1]. 


\subsection{Lack of Conceptual Clarity}

The effects of technology on self-care and self-management appear to be promising for the future. But in a further analysis of the studies in our review, we found serious limitations to the interpretation of the reported results regarding effects of technology on self-care and self-management. The first striking element of the included studies on patient self-care and self-management is the use of varied and inconsistent terminology: self-care, self-management, self-monitoring, self-regulation, adherence and compliance reveal a confused picture. The terms self-care and self-management are often used interchangeably or simultaneously, sometimes referring to knowledge or awareness, in other cases meaning maintaining health and managing a chronic illness. The need for conceptual clarity is not new. Already in 2003, authors started a discussion towards clearly defining self-management and its role in the delivery of health care to people with chronic disease. This lack of conceptual clarity is also discussed and described by Wilson et al. [47] in a study on self-management in long-term conditions. In comparing and contrasting definitions of self-care and self-management Wilson et al. [47] noted that definitions of self-management are more specific than those of self-care, although there are several common features. Both self-care and self-management involve a proactive process, compliance with professional advice, close attention to one's body, and having the appropriate coping behaviour. Wilson et al. [47] argue that the key difference between self-management and self-care is that in self-management patients undertake tasks that are within the traditional preserve of health professionals. Moreover, Song [48] reported that, despite the increased interest in self-care, there is no clear consensus among researchers and practitioners as to exactly how the concept of self-care should be defined. Finally, Schulman-Green et al. [49] described self-management as a dynamic process in which individuals actively manage a chronic illness. In a meta-synthesis of current descriptions of the self-management process, Schulman-Green et al. [49] identified three categories of self-management processes: (a) focusing on illness needs; (b) activating resources and (c) living with a chronic illness. The authors delineated tasks and skills for each category of self-management.

Accordingly, a significant deficiency in almost all the studies under review is that the authors do not refer to the current definitions and conceptualisation of self-care and self-management. Furthermore, the reported effects in most studies only relate to one or more aspects of self-care and self-management.

\subsection{Meta-Synthesis of the Concepts Self-Care and Self-Management}

Because we wanted to gain more insight into the concepts of self-care and self-management as described in the studies under review, we performed a meta-synthesis of the 33 studies. The goal of this exercise was to obtain a better understanding of what is meant by these concepts. When we examined the studies of our literature review in greater detail (see Table 3), we discovered that the described effects on self-care and self-management covered a number of different aspects. 
Table 3. New classification of patient outcome measurements.

\begin{tabular}{|c|c|c|c|c|}
\hline $\begin{array}{c}\text { Author and year of } \\
\text { publication }\end{array}$ & Type of patient & Competence & Illness-management & Independence \\
\hline \multicolumn{5}{|c|}{ Reviews } \\
\hline Paré et al., 2007 [1] & chronic diseases & $\begin{array}{l}\text { improvement of awareness and feeling of } \\
\text { security, leading to empowerment } \\
\text { active participation in the process of care }\end{array}$ & & \\
\hline $\begin{array}{c}\text { Bowles \& Baugh } \\
2007[2]\end{array}$ & $\begin{array}{c}\text { adult patients } \\
\text { with chronic illness }\end{array}$ & & $\begin{array}{l}\text { positive effects on } \\
\text { self-management }\end{array}$ & \\
\hline $\begin{array}{l}\text { Stumbo et al., } \\
2009[17]\end{array}$ & individuals with disabilities & $\begin{array}{l}\text { more control } \\
\text { more self confidence }\end{array}$ & & $\begin{array}{l}\text { assistive technology is a } \\
\text { foundational support that } \\
\text { produces multiple and } \\
\text { life-changing benefits }\end{array}$ \\
\hline $\begin{array}{l}\text { Gately et al., } \\
2008[18]\end{array}$ & $\begin{array}{c}\text { patients with } \\
\text { long-term conditions }\end{array}$ & $\begin{array}{c}\text { disruptive effects of health technologies } \\
\text { on personal identities } \\
\text { more self-regulation }\end{array}$ & $\begin{array}{l}\text { disruptive effects of health } \\
\text { technologies on strategies of } \\
\text { managing illness }\end{array}$ & \\
\hline $\begin{array}{c}\text { Jaana \& Paré, } \\
2007[19]\end{array}$ & diabetes & receptiveness, empowerment, education & $\begin{array}{l}\text { management of } \\
\text { medical condition }\end{array}$ & \\
\hline $\begin{array}{c}\text { Jaana et al., } \\
2007[20]\end{array}$ & hypertension & $\begin{array}{c}\text { significant reduction in blood pressure, } \\
\text { significant improvement of } \\
\text { disease knowledge }\end{array}$ & & \\
\hline \multicolumn{5}{|c|}{ Individual studies } \\
\hline $\begin{array}{l}\text { Gomez et al., } \\
2002[21]\end{array}$ & diabetes & $\begin{array}{l}\text { increasing patient empowerment } \\
\text { and education }\end{array}$ & & \\
\hline $\begin{array}{l}\text { Bujnowska-Fedak } \\
\text { et al., } 2011[22]\end{array}$ & diabetes & achieving a sense of independence & & \\
\hline $\begin{array}{c}\text { Bowles \& Dansky, } \\
2002[23]\end{array}$ & diabetes & improved knowledge (not significant) & improved self-management & \\
\hline
\end{tabular}


Table 3. Cont.

\begin{tabular}{|c|c|c|c|c|}
\hline $\begin{array}{c}\text { Author and year of } \\
\text { publication }\end{array}$ & Type of patient & Competence & Illness-management & Independence \\
\hline $\begin{array}{l}\text { Frühauf et al., } \\
\quad 2012[24]\end{array}$ & psoriasis patients & more flexible and empowered lifestyle & & \\
\hline $\begin{array}{l}\text { Finkelstein et al., } \\
2008[25]\end{array}$ & multiple sclerosis & & $\begin{array}{l}\text { improvement of } \\
\text { functional outcomes }\end{array}$ & \\
\hline $\begin{array}{l}\text { Pecina et al., } \\
2011[26]\end{array}$ & complex medical illnesses & $\begin{array}{c}\text { moderate increase in knowledge } \\
\text { earlier detection of decline in health status } \\
\text { increased personal awareness leading to } \\
\text { behavioural changes }\end{array}$ & & \\
\hline Marziali, 2009 [27] & chronic disease & $\begin{array}{l}\text { reduced sense of isolation, maintenance of } \\
\text { optimal healthcare strategies }\end{array}$ & & \\
\hline Kuo et al., 2012 [28] & stroke patients & & $\begin{array}{c}\text { reduce daily abnormal blood } \\
\text { pressure rate by } \\
\text { proper measurement }\end{array}$ & \\
\hline $\begin{array}{l}\text { LaFramboise et al., } \\
2009 \text { [29] }\end{array}$ & heart failure & & $\begin{array}{l}\text { ease of use, promote } \\
\text { comprehension and } \\
\text { self-management }\end{array}$ & \\
\hline $\begin{array}{l}\text { Dansky et al., } \\
2008[30]\end{array}$ & heart failure & $\begin{array}{l}\text { confidence is a predictor of } \\
\text { self-management behaviours }\end{array}$ & & \\
\hline $\begin{array}{c}\text { Bowles et al., } \\
2010 \text { [11] }\end{array}$ & heart failure & & $\begin{array}{l}\text { early identification of and } \\
\text { intervention in } \\
\text { clinical changes }\end{array}$ & \\
\hline $\begin{array}{l}\text { Finkelstein \& Wood, } \\
2011[31]\end{array}$ & heart failure & & $\begin{array}{l}\text { assumed utility in daily } \\
\text { self-management }\end{array}$ & \\
\hline
\end{tabular}


Table 3. Cont.

\begin{tabular}{|c|c|c|c|c|}
\hline $\begin{array}{c}\text { Author and year of } \\
\text { publication }\end{array}$ & Type of patient & Competence & Illness-management & Independence \\
\hline $\begin{array}{c}\text { Papasifakis \& } \\
\text { Vanderveen, } \\
2009[32]\end{array}$ & heart failure & & $\begin{array}{c}\text { improvement of self-care } \\
\text { improvement of disease } \\
\text { management }\end{array}$ & \\
\hline $\begin{array}{l}\text { Guendelman et al., } \\
2002 \text { [33] }\end{array}$ & paediatric asthma & $\begin{array}{c}\text { self-care behaviours improved far more } \\
\text { for the intervention group; } \\
\text { increased self-management skills }\end{array}$ & & improved asthma outcomes \\
\hline $\begin{array}{l}\text { Brennan et al., } \\
\quad 2010[34]\end{array}$ & $\begin{array}{l}\text { patients with chronic } \\
\text { cardiac disease }\end{array}$ & & better self-management & improved outcome \\
\hline $\begin{array}{l}\text { Vontetsianos et al., } \\
2005[35]\end{array}$ & COPD patients & improvement of disease knowledge & $\begin{array}{l}\text { improvement of } \\
\text { self-management }\end{array}$ & \\
\hline $\begin{array}{l}\text { Sicotte et al., } \\
2011[36]\end{array}$ & COPD patients & $\begin{array}{l}\text { improving attitudes and behaviours } \\
\text { concerning management of the illness }\end{array}$ & & \\
\hline $\begin{array}{l}\text { Wilson et al., } \\
2009 \text { [37] }\end{array}$ & people aging with disability & & $\begin{array}{l}\text { reducing or slowing down } \\
\text { functional and } \\
\text { frailty problems }\end{array}$ & $\begin{array}{l}\text { improved ability to gain or } \\
\text { maintain independence }\end{array}$ \\
\hline $\begin{array}{l}\text { Shea \& Chamoff, } \\
\quad 2012 \text { [38] }\end{array}$ & $\begin{array}{c}\text { patients with } \\
\text { chronic conditions }\end{array}$ & improved self-care behaviour & & \\
\hline $\begin{array}{c}\text { Cardozo \& Steinberg, } \\
2010[39]\end{array}$ & $\begin{array}{l}\text { patients with } \\
\text { chronic conditions } \\
\text { following discharge }\end{array}$ & improved disease understanding & & \\
\hline $\begin{array}{l}\text { Hoenig et al., } \\
2003 \text { [40] }\end{array}$ & disabled elderly & & $\begin{array}{c}\text { technological assistance may } \\
\text { be substituted for some } \\
\text { personal assistance }\end{array}$ & \\
\hline
\end{tabular}


Table 3. Cont.

\begin{tabular}{|c|c|c|c|c|}
\hline $\begin{array}{c}\text { Author and year of } \\
\text { publication }\end{array}$ & Type of patient & Competence & Illness-management & Independence \\
\hline $\begin{array}{l}\text { Chumbler et al., } \\
2004[41]\end{array}$ & frail elderly men & & & $\begin{array}{l}\text { improvement in functional and } \\
\text { cognitive outcomes }\end{array}$ \\
\hline Hui et al., 2006 [42] & $\begin{array}{l}\text { older women with } \\
\text { urinary incontinence }\end{array}$ & & $\begin{array}{l}\text { videoconferencing is as } \\
\text { effective as conventional } \\
\text { management }\end{array}$ & \\
\hline $\begin{array}{l}\text { Bewernitz et al., } \\
2009[43]\end{array}$ & dementia & increased independence in some tasks & & \\
\hline $\begin{array}{l}\text { Evans et al., } \\
2011[44]\end{array}$ & dementia & & & $\begin{array}{l}\text { potential tool to support } \\
\text { independent living }\end{array}$ \\
\hline $\begin{array}{l}\text { Mihailidis et al., } \\
2008 \text { [45] }\end{array}$ & dementia & & & improvement in independence \\
\hline $\begin{array}{l}\text { Maguire et al., } \\
2005[46]\end{array}$ & $\begin{array}{l}\text { cancer patients receiving } \\
\text { chemotherapy }\end{array}$ & & $\begin{array}{l}\text { improving symptom } \\
\text { management }\end{array}$ & \\
\hline
\end{tabular}


We also found that most of the reported effects were related to the improvement of disease knowledge or education, increased self-management skills, such as symptom management, and the improvement of attitudes and behaviours concerning management of the illness. We also discovered that these concepts contained a number of components, identified as, for instance: tasks, skills, self-management behaviour and self-management processes. This analysis continued until a final categorization was reached.

\subsection{New Classification of Outcome Measures}

Based on this knowledge, we made a new classification of outcome measures, with three hierarchical levels or stages:

(1) competence (a better understanding of the disease, disease knowledge);

(2) illness management (making choices, acting responsibly);

(3) independence (social participation, autonomy).

At the first stage, there is an increase in patient awareness of the disease and an increased knowledge of the symptoms; at this level, patients need the help of professionals to manage their disease. At the second stage, patients are increasingly involved in the care process, are able to manage the disease, can make important decisions, e.g., about the treatment, and the professional becomes a co-pilot. At the highest stage, patients are fully able to take care of themselves, participate in work or their social network, and live independently. The professional is out of sight.

We applied this tripartite division to the described effects and outcome measures of our literature review. For each study we looked in detail at the meaning of the described effects and attached a new label to the measurements, namely competence, illness management and independence. The results of this exercise are presented in Table 3. This new classification can be used to determine the stage of a patient's self-care or self-management process and what sort of skills and tasks are needed.

\subsection{Discussion}

This review aims to afford insight into the effects of technology in care at home on patient self-care and self-management by critically evaluating the literature on this topic. Although this is a relatively new research field, we found 33 studies with a focus on effects on patient outcomes. The huge diversity in research methods in the included studies reflects the newness of this research field.

Although almost all the authors in our review reported positive effects of technology on self-care and self-management, and underline the importance of promising technology, we did not, however, find strong evidence for these positive effects. Part of this is caused by the lack of a clear conceptualization of self-care and self-management. This is in line with the findings of Song [48] and Schulman-Green [49].

Most of the studies showed effects of technology in home-based care on competence level: in general, patients using certain types of technology have a better understanding of their disease and more knowledge about the disease. Also there are reported effects on illness management: patient self-care behaviour improved and patients were more capable of managing their medical condition and their illness. Only a few studies showed an effect on the highest level of our classification, namely 
independence: patients showing an improved ability to gain or maintain more independence or to live more independently using technology. We therefore conclude that the evidence for positive effects of technology in care at home on self-care and self-management, according to our tripartite classification, is not strong.

\subsection{Methodological Quality of the Studies}

A critical comment on the results of the studies under review concerns methodological quality. Besides the lack of clarity about the concepts self-care and self-management, an important shortcoming of many of the studies is that they consisted of pilot projects with relatively small numbers of patients, and were limited to specific patient groups (see Table 2). Furthermore, the duration of the interventions was relatively short-usually one year. Some studies had only one follow-up assessment. As a result, the magnitude of the described effects of technology on patients self-care and self-management is debatable, because of the variation in patients' characteristics (e.g., background, ability for self-management), small sample sizes with various types and doses of intervention, inconsistent selection of samples and different approaches to intervention and control groups.

Further, the research designs of the studies were very diverse. They included qualitative research, monitoring studies, cross-sectional research, single case studies and randomized controlled trials. In addition, only a third of the individual studies (nine studies) used both an intervention group (patients who use technology) and a control group (patients who received usual care). Concerning the methodology, most of the studies used patient questionnaires or patient (telephone) interviews.

\subsection{Strengths and Limitations}

The broad scope of our review is its main strength. Most of the studies on the effects of technology on patient self-care and self-management focus on one disease, a specific patient group or a particular setting. We brought the results together and gave an overview of the results of the thirty-three studies, including six review studies. This broad scope also has its drawbacks, namely in capturing the breadth of self-care and self-management more than the depth. Nonetheless, in the meta-analysis, we tried to reach a better understanding of self-care and self-management and to give more insight into the meaning and complexity of the concepts.

\subsection{Knowledge Gaps}

Self-care and self-management are often-used concepts, but to date there has been no agreement about their definition and operationalization in the literature. More effort is required to further operationalize the meaning of these concepts. Self-care and self-management processes include tasks, skills, and competences aimed at coping with the illness and integrating the illness in the context of an individual life. Research on the effects of technology in care at home is still in its infancy. Researchers should learn from the current body of knowledge in this area and address the issues of methodological quality of the studies that remain problematic. There is a lack of high quality evaluation research, and further evaluation studies should consider strong research designs, with a control group, with larger 
samples of patients and conducted over longer periods of time. Furthermore, we found that the use of validated instruments to measure effect on self-care and self-management was limited. But it is not only large scale research designs that are needed. Indeed, randomized control studies are not always the most appropriate in this relatively new research field. Qualitative research and realistic field studies are also important to gain more insight into the self-care and self-management process.

Future research is needed to clarify how technology can be used in care at home to maximize its benefits, to examine how and when patients engage in self-care and self-management, under what conditions, and to identify differences in self-care and self-management in patient characteristics, in specific diseases and in various settings. Only then will we be able to draw firmer conclusions regarding the effects of technology.

\section{Conclusions}

In this scoping review we did not find convincing evidence that technology in care at home has (a positive) effect on patient self-care and self-management. The reported effects are mostly concerned with competence, self-care behaviour and illness management. Less is known about the contribution of technology in care at home to helping patients remain independent. In general, patient outcomes in the included studies were positive, but most of the studies were pilot studies, with a small number of patients, had no control group and a short duration with only one follow-up assessment.

Management of a chronic disease and identification of the components of self-care and self-management are important for health care. These findings can help to guide future research and clinical practice that support self-management efforts.

\section{Authors' Contributions}

JP was responsible for the conception and design of the study, performed the data analyses and data synthesis, the assessments and interpretations of the data and drafted the manuscript. TW participated in the design of the study, was responsible for the assessments, performed the data analysis, data synthesis and data extraction, the interpretation of the data, and commented on the manuscript. RF contributed to the conception and design of the study and the manuscript and was responsible for the supervision. All authors read and approved the final manuscript.

\section{Acknowledgments}

We would like to thank Linda Schoonmade, librarian at NIVEL, for conducting the search strategy and screening the references of the relevant systematic reviews, and Anne-Vicky Carlier, likewise librarian at NIVEL, for gathering the extensive literature.

\section{Conflicts of Interest}

The authors declare no conflicts of interest. 


\section{References}

1. Paré, G.; Jaana, M.; Sicotte, C. Systematic review of home telemonitoring for chronic diseases: The evidence base. JAMA 2007, 14, 269-277.

2. Barlow, J.; Bayer, S.; Castleton, B.; Curry, R. Meeting government objectives for telecare in moving from local implementation to mainstream services. J. Telemed. Telecare 2005, 11, 49-51.

3. Bowles, K.H.; Baugh, A.C. Applying research evidence to optimize telehomecare. J. Cardiovasc. Nurs. 2007, 22, 5-15.

4. Rumberger, J.; Dansky, K. Is there a business case for telehealth in home health agencies? Telemed. J. e-Health 2006, 12, 122-127.

5. Barlow, J.; Wright, C.; Sheasby, J.; Turber, A.; Hainsworth, J. Self-management approaches for people with chronic illness: A review. Patient Educ. Couns. 2002, 48, 177-187.

6. Ryan, P.; Sawin, K.J. The individual and family self-management theory: Background and perspectives on context, process and outcomes. Nurs. Outlook 2009, 57, 217-225.

7. Black, A.D.; Car, J.; Pagliari, C.; Anandan, C.; Cresswell, K.; Bokun, T.; McKinstry, B.; Procter, R.; Majeed, A.; Sheikh, A. The impact of eHealth on the quality and safety of health care: A systematic overview. PLoS Med. 2011, 8, e1000387, doi:10.1371/journal.pmed.1000387.

8. Postema, T.R.F.; Peeters, J.M.; Friele, R.D. Key factors influencing the implementation success of a home telecare application. Int. J. Med. Inform. 2012, 81, 415-423.

9. Zwijsen, S.A.; Niemeijer, A.R.; Hertogh, C.M. Ethics of using technology in the care for community-dwelling elderly people: An overview of the literature. Aging Ment. Health 2011, 15, $419-427$.

10. Lorig, K.R.; Holman, M.D. Self-management education: History, definition, outcomes and mechanisms. Ann. Behav. Med. 2003, 26, 1-7.

11. Bowles, K.; Riegel, B.; Weiner, M.G.; Glick, H.; Naylor, M.D. The effect of telehomecare on heart failure self care. AMIA Annu. Symp. Proc. 2010, 2010, 71-75.

12. Riegel, B.; Dickson, V.V. A situation specific theory of heart failure self-care. J. Cardiovasc. Nurs. 2008, 23, 190-196.

13. Davis, K.; Drey, N.; Gould, D. What are scoping studies? A review of the nursing literature. Int. J. Nurs. Stud. 2009, 46, 1386-1400.

14. Levac, D.; Colquhoun, H.; O’Brien, K.K. Scoping studies: Advancing the methodology. Implement. Sci. 2010, 5, 69, doi:10.1186/1748-5908-5-69.

15. Arksey, H.; Malley, L.O. Scoping studies: Towards a methodological framework. Int. J. Soc. Res. Methodol. 2005, 8, 19-32.

16. Grant, M.; Booth, A. A typology of reviews: An analysis of 14 reviews types and associated methodologies. Health Inf. Libr. J. 2009, 26, 91-108.

17. Stumbo, N.J.; Martin, J.K.; Hedrick, B.N. Assistive technology: Impact on education, employment, and independence of individuals with physical disabilities. J. Vocat. Rehabil. 2009, 30, 99-110.

18. Gately, C.; Rogers, A.; Kirk, S.; McNally, R. Integration of devices into long-term condition management: A synthesis of qualitative studies. Chronic Illn. 2008, 4, 135-148. 
19. Jaana, M.; Paré, G. Home telemonitoring of patients with diabetes: A systematic assessment of observed effects. J. Eval. Clin. Pract. 2007, 13, 242-253.

20. Jaana, M.; Paré, G.; Sicotte, C. Hypertension home telemonitoring: Current evidence and recommendations for future studies. Dis. Manag. Health Outcomes 2007, 15, 19-31.

21. Gómez, E.J.; Hernando, M.E.; García, A.; del Pozo, F.; Cermeño, J.; Corcoy, R.; Brugués, E.; de Leiva, A. Telemedicine as a tool for intensive management of diabetes: The DIABTel experience. Comput. Methods Programs Biomed. 2002, 69, 163-177.

22. Bujnowska-Fedak, M.M.; Puchola, E.; Steciwko, A. The impact of telehomecare on health status and quality of life among patients with diabetes in a primary care setting in Poland. Telemed. $J$. e-Health 2011, 17, 153-163.

23. Bowles, K.H.; Dansky, K.H. Teaching self-management of diabetes. Home Healthc. Nurse 2002, $20,36-42$.

24. Frühauf, J.; Schwantzer, G.; Ambros-Rudolph, M.; Weger, W.; Ahlgrimm-Siess, V.; Salmhofer, W.; Hofmann-Wellenhof, R. Pilot study on the acceptance of mobile teledermatology for the home monitoring of high-need patients with psoriasis. Australas. J. Dermatol. 2012, 53, 41-46.

25. Finkelstein, J.; Lapshin, O.; Castro, H.; Cha, E.; Provance, P.G. Home-based physical telerehabilitation in patients with multiple sclerosis: A pilot study. J. Rehabil. Res. Dev. 2008, 45, 1361-1374.

26. Pecina, J.L.; Vickers, K.S.; Finnie, D.M.; Hathaway, J.C.; Hanson, G.J.; Takahashi, P.Y. Telemonitoring increases patient awareness of health and prompts health-related action: Initial evaluation of the TELE-ERA study. Telemed. J. e-Health 2011, 17, 461-466.

27. Marziali, E. e-Health program for patients with chronic disease. Telemed. J. e-Health 2009, 15, $176-181$.

28. Kuo, Y.H.; Chien, Y.K.; Wang, W.R.; Chen, C.H.; Chen, L.S.; Liu, C.K. Development of a home-based telehealthcare model for improving the effectiveness of the chronic care of stroke patients. Kaohsiung J. Med. Sci. 2012, 28, 38-43.

29. LaFramboise, L.M.; Woster, J.; Yager, A.; Yates, B.C. A technological life buoy: Patient perceptions of the Health Buddy. J. Cardiovasc. Nurs. 2009, 24, 216-224.

30. Dansky, K.H.; Vasey, J.; Bowles, K. Use of telehealth by older adults to manage heart failure. Res. Gerontol. Nurs. 2008, 1, 25-32.

31. Finkelstein, J.; Wood, J. Implementing Home Telemanagement of Congestive Heart Failure Using Xbox Gaming Platform. In Proceedings of the 33rd Annual International Conference of the IEEE EMBS, Boston, MA, USA, 30 August-3 September 2011; pp. 3158-3163.

32. Papasifakis, B.K.; Vanderveen, S. Self-care strategies are critical to disease management in home care. Heart Lung J. Acute Crit. Care 2009, 38, 263.

33. Guendelman, S.; Meade, K.; Benson, M.; Chen, Y.Q.; Samuels, S. Improving asthma outcomes and self-management behaviors of inner-city children. Arch. Pediatr. Adolesc. Med. 2002, 156, 114-120.

34. Brennan, P.F.; Casper, G.R.; Burke, L.J.; Johnson, K.; Brown, R.; Valdez, R.S.; Sebern, M.; Perez, O.; Sturgeon, B. Technology-enhanced practice for patients with chronic cardiac disease: Home implementation and evaluation. Heart Lung 2010, 39, S34-S46. 
35. Vontetsianos, T.; Giovas, P.; Katsaras, T.; Rigopoulou, A.; Mpirmpa, G.; Giaboudakis, P.; Koyrelea, S.; Kontopyrgias, G.; Tsoulkas, B. Telemedicine-assisted home support for patients with advanced chronic obstructive pulmonary disease: Preliminary results after nine-month follow-up. J. Telemed. Telecare 2005, 11, S1:86-S1:88.

36. Sicotte, C.; Paré, G.; Morin, S.; Potvin, J.; Moreault, M.P. Effects of home telemonitoring to support improved care for chronic obstructive pulmonary diseases. Telemed. J. e-Health 2011, 17, 95-104.

37. Wilson, D.J.; Mitchell, J.M.; Kemp, B.J. Adkins, R.H.; Mann, W. Effects of assistive technology on functional decline in people aging with a disability. Assist. Technol. 2009, 21, 208-217.

38. Shea, K.; Chamoff, B. Telehomecare communication and self-care in chronic conditions: Moving toward a shared understanding. Worldviews Evid. Based Nurs. 2012, 9, 109-116.

39. Cardozo, L.; Steinberg, J. Telemedicine for recently discharged older patients. Telemed. J. e-Health 2010, 16, 49-55.

40. Hoenig, H.; Taylor, D.H., Jr.; Sloan, F.A. Does assistive technology substitute for personal assistance among the disabled elderly? Am. J. Public Health 2003, 93, 330-337.

41. Chumbler, N.R.; Mann, W.C.; Wu, S.; Schmid, A.; Kobb, R. The association of home-telehealth use and care coordination with improvement of functional and cognitive functioning in frail elderly men. Telemed. J. e-Health 2004, 10, 129-137.

42. Hui, E.; Lee, P.S.; Woo, J. Management of urinary incontinence in older women using videoconferencing versus conventional management: A randomized controlled trial. J. Telemed. Telecare 2006, 12, 343-347.

43. Bewernitz, M.W.; Mann, W.C.; Dasler, P.; Belchior, P. Feasibility of machine-based prompting to assist persons with dementia. Assist. Technol. 2009, 21, 196-207.

44. Evans, N.; Carey-Smith, B.; Orpwood, R. Using smart technology in an enabling way: A review of using technology to support daily life for a tenant with moderate dementia. Br. J. Occup. Ther. 2011, 74, 249-253.

45. Mihailidis, A.; Boger, J.N.; Craig, T.; Hoey, J. The COACH prompting system to assist older adults with dementia through handwashing: An efficacy study. BMC Geriatr. 2008, 8, 28. doi:10.1186/1471-2318-8-28.

46. Maguire, R.; Miller, M.; Sage, M.; Norrie, J.; McCann, L.; Taylor, L.; Kearney, N. Results of a UK based pilot study of a mobile phone based advanced symptom management system (ASyMS) in the remote monitoring of chemotherapy related toxicity. Clin. Eff. Nurs. 2005, 9, 202-210.

47. Wilson, P.M.; Kendall, S.; Brooks, F. Nurses' responses to expert patients: The rhetoric and reality of self-management in long-term conditions: A grounded theory study. Int. J. Nurs. Stud. 2006, 43, 803-818.

48. Song, M. Diabetes mellitus and the importance of self-care. J. Cardiovasc. Nurs. 2010, 25, 93-98. 
49. Schulman-Green, D.; Jaser, S.; Martin, F.; Alonzo, A.; Grey, M.; McCorkle, R.; Redeker, S.; Reynolds, N.; Whittermore, R. Processes of self-management in chronic illness. J. Nurs. Scholarsh. 2012, 44, 136-144.

(C) 2013 by the authors; licensee MDPI, Basel, Switzerland. This article is an open access article distributed under the terms and conditions of the Creative Commons Attribution license (http://creativecommons.org/licenses/by/3.0/). 